1. Мазур О.В., Степанов М.Т. Моделювання процесів управління пастеризаційно-охолоджувальною установкою у середовищі МАТLAВ // Наук. пр. ОДАХТ / Міністерство освіти України. - Одеса: 2001. Вип. 22. - С. $124-128$.

2. Хобин В.А., Мазур А.В. ІІовышение эффективности и ресурса эксплуатации абсорбционных холодильных машин средствами гарантирующего управления // Системный анализ, управление и информационные технологии: Сб. науч. тр. 12-ой Международ. конф. по автомат. упр-нию «Автоматика - 2005»/ Харьков: Н'ТУ «ХІІИ», 2005. - № 55. - С. $19-24$.

3. Хобин В.А., Мазур А.В. Управление процессом очистки растительных масел от восков // Олійножировийкомплекс - لніпропетровськ, 2004. - № I (4). - С. 46 - 48.

\title{
ПРО ВПЛИВ РЕЖИМУ ЕКСПЛУАТАЦІЇ ТЕХНІЧНИХ ОБ'ЄК'ТІВ НА ЇХНЮ НАДІЙНІСТЬ
}

\author{
Воінова С. О., канд. техн. наук, доцент \\ Одеська національна акацемія харчових технологій
}

Проанализировано влияние режииа эксплуатаиии технических объектов на их надежность.

Influencing of the exploitation mode of technical objects on their reliability is parsed. Voinova S. A. About the influencing of the exploitation mode of technical objects on their reliability

Ключові слова: технічний об'єкт, надійність, режим експлуатації, вплив.

Надійність (Нд) - важлива технологічна властивість технічного обєєкта (ТО). На Нд впливає безліч чинників різного роду. Найбільш істотний вплив режиму експлуатації ТО.

Розглянемо вплив цього чинника.

Режим експлуатації (виробничого використання) ТО складається 3

режиму технічного застосування, на який впливають фактори:

вплив технологічного потоку речовини, що переробляеться, або енергії (навантаження технологічному) вплив комплексу зовнішніх і внутрішніх, детермінованих і випадкових джерел збурювань різного роду, керуючий вплив;

режиму технічного обслутовування ТО, на який впливають фактори:

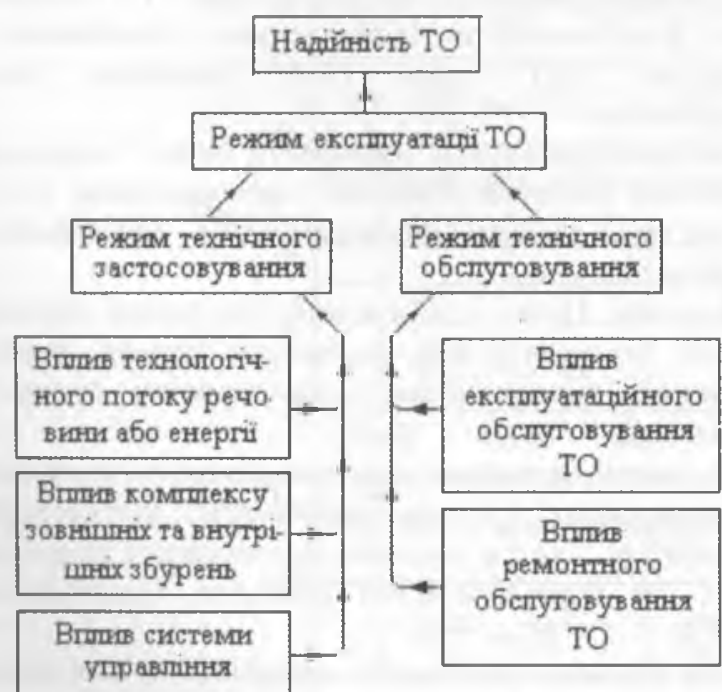

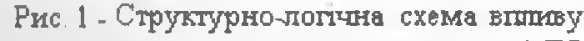
складових режиму експиуатагдіi TO

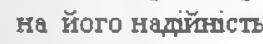

експлуатаційне обслуговування - оперативна компенсація поточних відхилень стану ТО від його регламентованого рівня - i

ремонтне обслуговування - наступна компенсації відхилень стану ТО від його регламентованого рівня.

На рис. 1 наведено структурно-логічну схему, шо розкриває зазначений зв'язок Нд ТО й режиму його експлуатації.

На технологічну ефективність ТО, зокрема, на важливу iï складову - Нд - впливає час, тривалість роботи, у процесі якої об'єкт перетерплює фізичне зношування. При цьому, його властивості й характеристики деградують, погіршуються.

Привертає увагу важлива обставина: вплив часу проявляється у двох напрямках.

ІІерший напрямок. У момент $\left(\mathrm{T}_{0}\right)$ пуску в роботу нового ТО його вихідна Нд (Ндисх характеризується максимальним значенням (рис. 2). У цей момент Нд потенційна (Ндпот), тобто доступна для використання, рівна $\left(\mathrm{H}_{\text {исх }}\right)$. Із часом, внаслідок зношування ТО, його Нд пот безупинно знижуеться: графік Нд пот (Т). Так, у момент часу $\mathrm{T}_{\mathrm{i}}$ ще зниження становить $\left(\mathrm{H}_{\text {иск }}-\mathrm{H}_{\text {пот і }}\right)$.

Другий напрямок. У момент $\left(\mathrm{T}_{0}\right)$ пуску в роботу нового ТО його фактична (реалізована) Нд (Н $\left.д_{\phi к}\right)$ ) характеризується максимальним значенням. При этон, має місце рівняння

$$
\mathrm{H}_{\text {фкт }}=\mathrm{H}_{\text {исх. }}=\mathrm{H}_{\text {пот }}
$$

Із часом, внаслідок зношування, безупинно змінюються властивості ТО. у їхньому числі змінюються властивості його як об'єкта управління (тобто змінюються регулювальні характеристики об'єкта). У той же час, 
алгоритм керування, розроблений для нового ТО, залишається незмінним. Із часом він усе більшою мірою відстає від мінливих властивостей керованого їм ТО. У результаті цього, якість управління об'єктом безупинно знижуєт,ся. Рівень ИД відстає від рівня Нд пот.

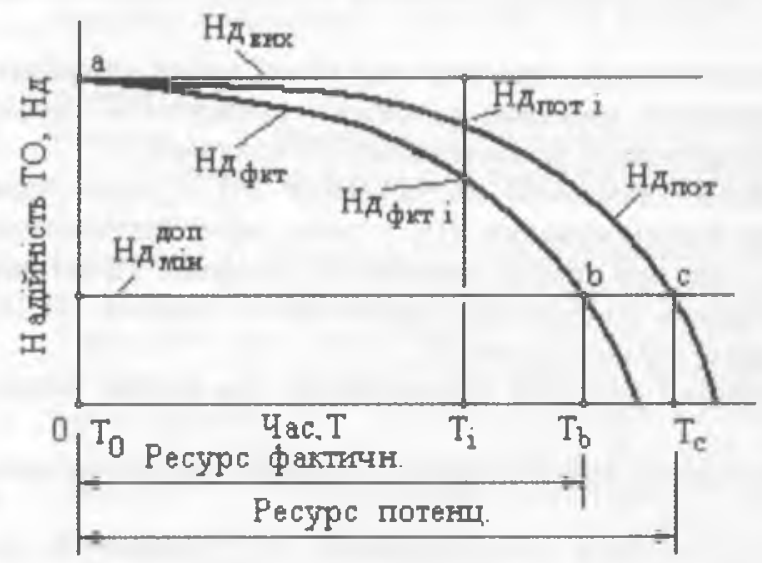

Так, у момент часу $\mathrm{T}_{\mathrm{i}}$ це зниження становить $\left(\right.$ Нд $\left._{\text {пот і }}-\mathrm{H}_{\text {фк і і }}\right)$.

Відзначимо те, що функції Нд(Т), зображені на рис. 2, гладкі, тому що відбивають теоретичні вистави про роботу ТО в умовах відсутності випадкових впливів, цо обурюють.

Розглянемо вплив режиму технічного застосування на Нд ТО (рис. 1).

Технологічний потік речовини або енергіï, що протікає через ТО, що й перероблясться їм, відбивас рівень його навантаження. Навантаження є основним із числа джерел, що обурюють виливів, випробовуваних об'єктом. Цей параметр технологічного процесу визначає рівень його напруженості й, В остаточному підсумку, сильно впливає па рівень Нд ТО [1], Нд і навантаження ТО перебувають у зворотній залежності.

Комплекс зовнішніх і внутрішніх впливів, що обурюють, надходять на ТО, відбиває якісні показники зазначеного вище потоку на вході й на виході з ТО, а також умови його реального функціонування.

Розглянемо результат впливу зовнішніх і внутрішніх, детермінованих і випадкових факторів на ТО. Так, якщо в момент часу Ть виникає технічна годія, що обумовлює зниження Нд ТО на розмір (Нд - Нд ) (рис. 3), те на траєкторії руху ТО на плошині (координатній сітці) «Нддд» утворюеться уступ (сходинка) між крапками b і с (рис. 3, жирна лінія).

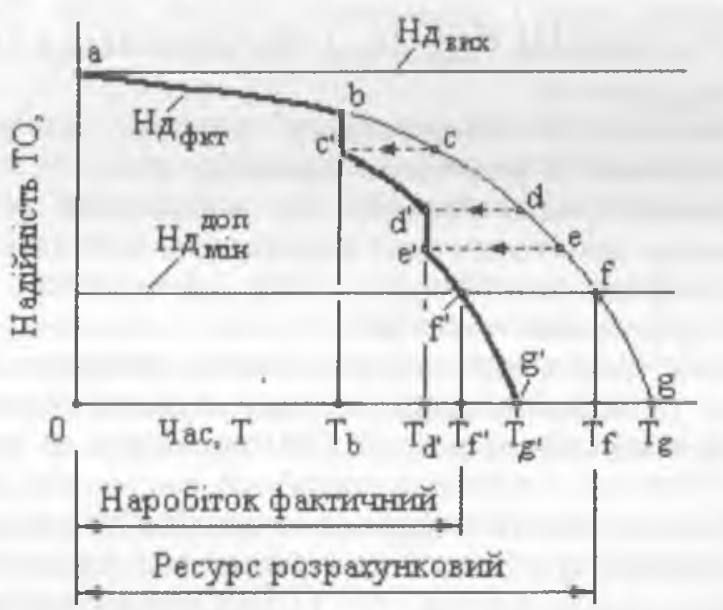

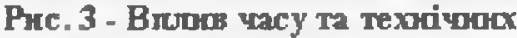 подій ка кадійогість ТO}

Ilicля цього траєкторія зберігає закон зниження Нд даного об'єкта; дуга (c - d) эквидистантна в горизонтальному напрямку дузі $(\mathrm{c}-\mathrm{d})$ характеристиці, цо належить, Нд(Т) об'єкта (зображеною дугою $(\mathrm{a}-\mathrm{b}-\mathrm{c}-\mathrm{d}$ $-\mathrm{e}-\mathrm{f}-\mathrm{g})$.

Якщцо в момент $\mathrm{T}_{\mathrm{d}}$ виникає нова технічна подія, що обумовлюе зниження Нд ТО на розмір $\left(\mathrm{H}_{\mathrm{d}}-\mathrm{H}_{\mathrm{e}}\right)$ (рис 3), те, що, аналогічно попередньому, на траєкторії руху ТО утворюється уступ між крапками d i e. Після цього траєкторія зберігає закон зниження Нд об'єкта; дуга (e - f - g ) эквидистантна в горизонтальному напрямку дузі ((e $f-g)$ характеристиці, що належить, Нд(Т) об'єкта.

Таким чином, внаслідок виникнення двох технічних подій, теоретична, гладка траєкторія Нд(т) ТО - (a-b-c - d $-\mathrm{e}-\mathrm{f}$ - поступилася місцем траєкторії реальної, негладкої - ( d' - e' - f'). Практичні наслідки цього полягають у наступному.

У теоретичному випадку розрахунковий ресурс працездатності розглянутого ТО визначається моментом

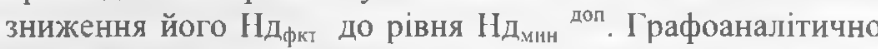
ресурс зизначається абсцисою крапки перетинання траєкторії руху ТО 3 горизонталлю Нд зазначена крапка позначена через «f». П̈̈ абсциса в масштабі графіка НД фкт (Т) обмежує розмір ресурсу розрахункового (теоретичного) розглянутого ТО.

У реальному випадку фактичний ресурс працездатності розглянутого ТО, за аналогією, визначається крапкою «f».

Аналіз викладеного показує, що розглянуті дві технічні події обумовили збиток у сфері технічного застосування ТО, який виражається скороченням ресурсу ТО на період довжиною, пропорційної, у масштабі осі абсцис, відрізку

$$
\left(\mathrm{Tf}-\mathrm{T}_{0}\right)-\left(\mathrm{Tf}-\mathrm{T}_{0}\right)=(\mathrm{Tf}-\mathrm{Tf}) \text {. }
$$

Цікаве питання про відношення розміру скоО, тобто - про питомий збиток. На початковій ділянц траєкторії ТО мало зношений, мало податливий негативному впливу, однак на цій ділянці питомий збиток найбільш значний. На кінцевій ділянці траєкторії має місце зворотна картина. ІІоснення криється в характері функції «Нд(Т)». 
Комплекс впливів, що обурюють, впливають на Нд ТО, включає групу впливів технологічних чинників. а також містить групу керуючих впливів, здійснюваних оперативним персоналом вручну, що й надходять від системи автоматичного угравління. Впливи другої групи спрямовані на виключення відхилень стану й параметрів функціонування ТО від нормативних, установлених діючим технічним регламентом. Відзначимо те, що помилки в діях персоналу й збої в роботі автоматики здатні негативно впливати на рівень технологічної ефективності ТО, зокрема, на рівень його Нд.

Слід зазначити та важлива обставина, що виникаючі технічні події, незалежно від їхньої істоти, ириводять не тільки до зниження Нд ТО; вони обумовлюють негативні наслідки, у вигляді зниження в цілому технологічної ефективності ТО, у тому числі екологічної, економічної й загальтехнічної ії складових.

Слід зазначити те, що ідеально сприятливе здійснення технічного застосування ТО в стані лише забезпечити проектні стан і найбільш високий показники функціонування ТО, у тому числі технологічну ефективність, на всім протязі траскторії витрати ресурсу, яка при цьому виявлясться гладкою. Практично неминучі в реальних виробничих умовах технічні події знижують технологічну ефективність, зокрема, Нд ТО. Подібний збиток компенсації засобами технічного застосування ТО не піддається.

Практика виробництва свідчить: чим вище рівень технічної культури підприємства, гем менше збиток, нанесений технічними подіями, тем вище Нд устаткування.

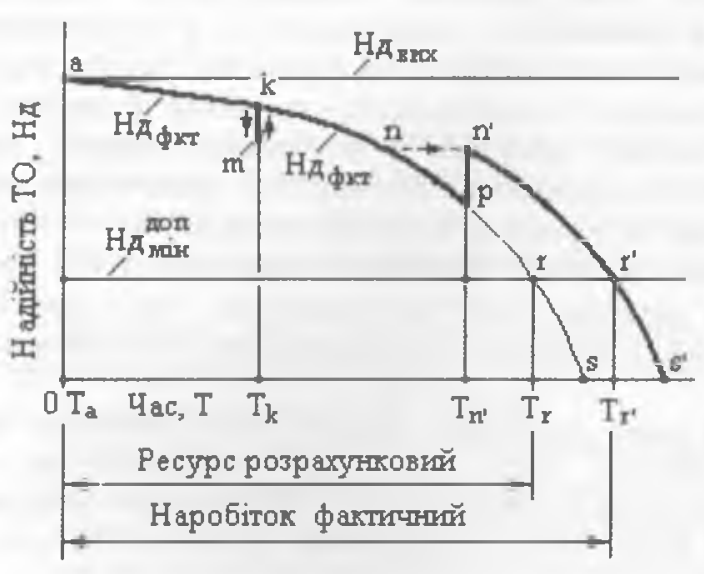

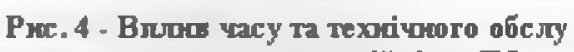
rosyearoc ha кадійтicts TO

Розглянемо вІлив режиму технічного обслуговування на Нд ТО (рис. 1).

Експлуатаційне обслуговування ТО призначене для оперативної компенсації поточних відхилень стану ТО від його регламентованого рівня. Його вплив на Нд ТО велике, тому що, що допускаються персоналом порушення правил обслуговування здатні викликати технічні події із серйозними негативними наслідками. Торкнемося деяких особливостей зазначеного впливу.

Розрахунковий ресурс ТО, динамічна характеристика Нд(Т) якого наведена на рис. 4 , визначається абсцисою іï

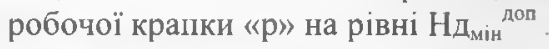

$\mathrm{y}$ момент часу $\mathrm{T}_{\mathrm{k}}$ зафіксована технічна подія. Воно привело до зниження $\mathrm{Hд}_{\text {фкт }} \mathrm{H}_{\text {фк }}$ від рівня $\left(\mathrm{H}_{д_{\phi к}}\right)_{\mathrm{k}}$ до рівня (Нд фк $_{\mathrm{m}}$ (рис. 4$)$.

Прийнятими в оперативному порядку заходами експлуатаційного й ремонтного характеру стан ТО було нормалізовано; рівень його Нд був відновлений тобто доведений до рівня $\left(\text { Н }_{\text {фкт }}\right)_{k}$. Таким чином, у процесі виникнення зазначеного події й проведення відбудовного

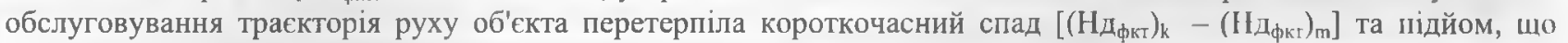

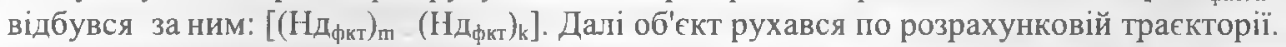

Коли ТО перебував у крапці «р» траєкторії, а його залишковий ресурс становив близько $30 \%$ розрахункового, а рівень Нд становив (Ндфкт), у момент часу Tn здійснене ремонтне обслуговування об'єкта у вигляді відновлення (технічного переозброєння). У результаті проведення робіт, Нд ТО підвишена до рівня $\left(\mathrm{H}_{\text {фкт }}\right)_{\mathrm{n}^{\prime}}$

Подальший хід траєкторії ТО здійснюеться відповідно до його динамічної характеристики (Нд(Т)) - по дузі $(\mathrm{n}-\mathrm{r}-\mathrm{s})$. IЦя дуга эквидистантна в горизонтальному напрямку дузі $(\mathrm{n}-\mathrm{r}-\mathrm{s})$, тобто вона $є$ динамічною характеристикою об'єкта, переміщеної уздовж осі часу на його відрізок (період) - $(r-r)$. IЦей відрізок відбиває отриманий ефект збільшення ресурсу ТО, обумовлений проведеним ремонтним обслуговуванням відновленням.

Технічне обслуговування ТО є діючим засобом впливу на стан і технологічну ефективність, у тому числі Нд, функціонування ТО. Відновлення ТО дозволяє підвищити не тільки їх Нд. Воно дозволяе збільшити їхню технологічну ефективність у цілому. Ремонтне обслуговування у вигляді відновлення ТО з малим залишковим ресурсом здатне привести до істотного результату $[2,3]$.

Слід зазначити те, що належне технічне обслуговування в стані зменшити негативні наслідки пюдій, що виникають у сфері застосування ТО. Більше того, експлуатаційне й ремонтне обслуговування в ряді випадків у стані підвищити технологічну ефективність, у тому числі Нл, функціонування ТО. Вище наведений подібний приклад.

Вплив на режим технічного застосування й на режим технічного обслуговування ТО дозволяє управляти рівнем його Нд $[4,5]$.

\section{Висновки}

1. Режим експлуатації ТО суттєво впливає на них Нд.

2. Порушення регламенту застосування TE здатне негативно впливати на них Нд. 
3. Порушення регламенту технічного обслуговування здатне негативно впливати на Нд ТО. Однак, застосування належного ремонтного обслуговування, з метою відновлення або відновлення ТО, дозволяє підвищити в певних межах їх Нд.

4. За допомогою засобів технічного застосування й технічного обслуговування ТО можна управляти їх Нд

5. На Нд ТО істотний вІлив виявляє рівень технічної культури, шо існуєнп на підшриємстві у тому числі важливої ії складової - технологічної культури

\title{
Jiтература
}

1. Воинова С. А. Воинов А. ІІ. Роль нагрузки в задачах управления надежностью технологических агрегатов // Сб. «Тепловые режимы и охлаждение радиозлектронной аппаратуры». Одесса: НИИ «IIторм», 1994, № 12. - C. $68-73$.

2. Воінова С. О. Можливості підвищення надійності технічних об'єктів з малим залишковим ресурсом. // 36. наук. пр. «Прогресивні техніка та технології харчових виробництв, ресторанного господарства і торгівлі».Харк. держ. ун-т харчування та торгівлі. - 2009. - Вип. I(9). - С. $307-313$.

3. Воінова С. А. Влияние цлительности функционирования технических объектов на их технологическую эффективность // 3б. матер. 5-ої Міжнар. н.-Іракт. конф. "Управління ефективним енерговикористанням“ (4 - 5 вересня 2003 р., Одеса). - Одеса: Вид. ТЕС, 2003.- С. 89 - 90.

4. Воинова С. А. Управление переходными процесами технологических машин при ограничениях на их режимы работы. // Тез. докл. 1-ой націон., науч.-грактич, конф. «Хлебопродукты-94». (14-16 сент. 1994 г.). - Одесса: 1994.

5. Хобін А. А., Воінова С. О. Підвишення надійності технологічного обладнання АПК при заданому рівні безаварійності // Тези допов. Міжнар. наук.-техн. конф. «Розробка та впровадження нових технологій і обладнання у харчову та переробні галузі АПК». - Київ, 19-21 жовтня 1993. - Київ: КТІХП. 1993.

\section{ДИАГНОСТИРОВАНИЕ ДЕРМАТОЛОГИЧЕСКИХ ЗАБОЛЕВАНИЙ ПАЦИЕНТОВ С ПОМОЩЬЮ ИСКУССТВЕННОЙ НЕЙРОННОЙ СЕТИ}

\author{
Высоцкая Е.В., К.Т.Н., доцент, Кириченко Ю.В., \\ Жукова Н.В., врач-дерматолог 2-го городского КВД \\ Харьковский национальный университет радиозлектроники
}

B cтатье были рассиотрены вопросы создания нейронной сети, позволяюицей определять дерматологические заболевания по клинико-биохимическии показателяи паииентов с учетои кооперативного взаимодействии интегративных систел контроля гомеостаза - эндокринной, нервной и иммунной и принципа системно-антисистемного взаимодействия.

The article examined the creation of a neural network, which allows to determine the dermatological diseases on the clinical and biochemical parameters of patients in the light of the cooperative interaction of integrative control systems of homeostasis - the endocrine, nervous and immune system-and the principle of anti-system interaction.

Ключевые слова: искусственная нейронная сеть, классификация, клинико-биохимические показатели, дерматозы.

Кожа является сложным органом, который играет важную роль в жизнедеятельности организма. IІричины возникновения кожных заболеваний разнообразны и сложны. Кожа постоянно подвергается воздействию химических соединений окружающей среды, различных грибков, вирусов, бактерий, что приводит к метаболическим изменениям в составе кожи. Все кожные заболевания сопровождаются определенными вторичными манифестными признаками и симптомами: сыпью, зудом и др.

Важной медико-социальной проблемой является широкая распространенность различных дерматозов, особенно в индустриально развитых странах, что сопровождается формированием тяжелых, резистентных к лечению, инвалидизирующих форм заболевания у значительного числа пациентов.

Хронические папулезные и зудящие дерматозы - группа наиболее распространенных и недостаточно изученных дерматозов, имеющих хроническое рецидивирующее течение, полиморфность клинической симптоматики, связанной с системными нарушениями различных физиологических функций организма. Проблема этиологии, патогенеза и рационального лечения этой патологии остается весьма актуальной в современной дерматологи.

В настоящее время псориаз является одним из самых распространенных хронических дерматозов, который встречается примерно у 1-3\% населения планеты, что составляет до $12-15 \%$ всех дерматозов. Отмечается постоянный рост больных экземой, что составляет $30-40 \%$ всех кожных заболеваний. Акне поражает около 80 